\title{
ВИКОРИСТАННЯ ІМЕРСИВНИХ ТЕХНОЯОГІЙ У ВИЩІЙ ВІЙСЬКОВІЙ ОСВІТІ УКРАЇНИ: ІСТОРИЧНІ АСПЕКТИ ТА СУЧАСНІСТЬ
}

У статті висвітлено історичні аспекти досвіду використання імерсивних технологій у підготовці майбутніх військових у закладах вищої освіти України.

Акцентовано, щъо на съогодні імерсивні технології широко використовуються в усіх галузях, зокрема - військовій освіті. Констатовано, ще аналіз наукового доробку вітчизняних науковців щодо використання імерсивних технологій у військовій підготовцуі засвідчив недостатню розробленість цієё проблеми, щзо підкреслило актуальність тели статті.

Розкрито сутність понять «імерсивні технологї», «віртуальна реальність», «доповнена реальність», «змінана реальність». Висвітлено континуум Мілграма «реальність - віртуальність», у якому віртуальна реальність виступае як середовище повного занурення у синтетичний світ із можливістю взаемодії.

Окреслено історію використання у військовій сфері в Украйні та за кордоном тренажерів i симуляторів. Наголошено на значенні та необхідності імерсивних технологій у підготовиі військових фахівців, особливо щодо максимального наближення віртуальних умов до реальних, можливості імітацї будь-які деталі, враховуючи фізику, створення нескінченної кількості сценаріїв та їх комбінацій.

Подано інформаццію про підприємства, які нині випускають повнофункціональні тренажери для військової сфери та окремі їх види для різних видів військової підготовки. Висвітлено досвід використання імерсивних тренажерів та симуляторів у Військовому інституті танкових військ Національного технічного університету «Харківський похітехнічний інститут», у Харківському авіаційному університеті, Військовому інституті телекомунікацій та інформатизациї̈ імені Героїв Крут.

Наголошено, щь використання імерсивних технологій у військовій освіті залишає певний відбиток на діяльності науково-педагогічних кадрів закладів вищої військової освіти. Зокрема, ключовим завданням військових фахівців, які забезпечують освітній процес, є адміністрування віртуального освітнього середовищца.

Зроблено висновок, що тренажери та симулятори із використанням імерсивних технологій містять величезний потенціал для системи підготовки військових Украйни, адже здатні впливати на їхню свідомість та готувати майбутніх фахівців в умовах, максимально наближених до реальності, тим самим підвицуючи ефективність навчання.

Ключові слова: вища військова освіта, імерсивні технології, тренажери, силулятори, майбутні військові.

Постановка проблеми. У сучасному суспільстві імерсивні технології з'явилися як нова область міждисциплінарних досліджень. Останніми роками обсяг їх використання вийшов за межі академічних досліджень. Такі галузі, як біомедична інженерія, структурне проєктування та сектор технологій, інвестують у цю технологію. Військова промисловість, що завжди шукає нові ідеї, повільно стає одним з основних інвесторів у AR (доповнена реальність) таVR (віртуальна реальність).

*C) Кохановська О. В.

U3 
Звісно, військова освіта щороку зазнає суттевих змін та інноваційних підходів, які спрямовані на підвищення іiі якості та відповідають світовим стандартам.Сьогодні майже всі заклади вищої освіти організовують освітній процес із використанням сучасних інформаційно-цифрових технологій. Дослідження показали, що імерсивні технології (зокрема, доповнена тавіртуальна реальність) мають значний потенціал для допомоги студентам у вдосконаленні своїх навичок і знань [15, с. 68].

Аналіз досліджень. Аналіз наукового доробку щодо системи вищої військової освіти в Україні засвідчив, що окремі аспекти їі вдосконалення вже були предметом уваги широкого кола науковців. Так, розвиток професійно важдивих рис військових розглядали А. Галімов, Д. Іщенко, В. Мірошніченко, О. Ставицький, В. Ягупов та ін. Проблеми підготовки майбутніх військових висвітлено у працях В. Береки, Й. Гушеля, О. Торичного та ін.

Питання впдиву імерсивних технологій на підвищення рівня мотивації студентів розглядаються у дослідженнях таких науковців, як-от: С. Аитвинова, Н. Осипова, Г. Попова, С. Семеріков, Н. Слюсаренко, А. Стрюк, М. Шишкіна та ін.

Мета статті - проаналізувати історичні аспекти та досвід використання імерсивних технологій у підготовці майбутніх військових у вишахУкраїни.

Виклад основного матеріалу. 25 березня 2021 року було прийнято Стратегію військової безпеки України, у якій одним з пріоритетних завдань визначено «розвиток систем військової освіти та підготовки особового складу для сил оборони, запровадження освітньо-професійних програм підготовки офіцерського, сержантського та старшинського складу з використанням досвіду бойових дій, методики підготовки, принципів і стандартів НАТО» [10].

Із уведенням карантинних обмежень в умовах пандемії COVID19 у закдадах вищої військової освіти активно використовуються методи організації навчальних занять із застосуванням інноваційних педагогічних технологій: мультимедійних інтерактивних програм; 3D-турів; підкастів; VR; AR тощо.

Однак, ураховуючи істотні обмеження поставок нової техніки у заклади вищої військової освіти, найбільш доцільним є використання імерсивних технологій.

Імерсивність (від «immersive» - створюючий ефект присутності, занурення) визначають як занурення у певні, штучно сформовані умови. Вона включає доповнену реальність AR (augmentedreality), віртуальну реальність VR (virtualreality), змішану реальність MR (mixedreality) і штучний інтелект AI (artificialintelligence) [3].

Доповнена реальність - результат введення в поле сприйняття будь-яких сенсорних даних 3 метою доповнення відомостей про оточення та покращення сприйняття інформації.

Віртуальна реальність - створений технічними засобами світ, що передається людині через їі відчуття: зір, слух, дотик та інші. Вона імітуе як відчуття, так і реакції на них. Для створення перекондивого компдексу відчуття реальності здійснюеться комп'ютерний синтез властивостей та реакцій у реальному часі [14].

Сама ідея використання технологій віртуальної реальності виникла в Сполучених Штатах Америки наприкінці 70-х років XX століття та спочатку була реалізована усистемі для військових Headsight (це був відеошлем із вбудованою системою відслідковування повороту голови), проте була засекреченою, а тому довгий час не презентувалася науковій спільноті [13; 16].

1994 року Пол Мілграм і Фуміо Кіширо запровадили термін «змішана реальність» у статті «Таксономія змішаної реальності візуальних дисплеїв», у якій визначили континуум «реальність - віртуальність», у якому віртуальна реальність виступає 
як середовище повного занурення у синтетичний світ із мождивістю взаємодії [8, с. 300] (рис.1).

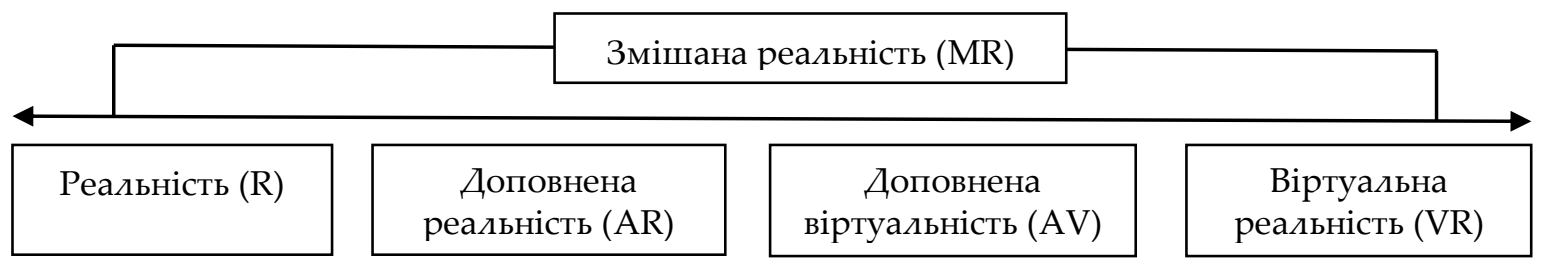

\section{Рис. 1. Континуум Мізграма}

В англомовній Вікіпедії є також трактування поняття «розширена реальність» (Extendedreality (XR)) - надмножина, яка вкдючає весь спектр від «повного реального» до «повного віртуального» в концепції континууму реальність-віртуальність П. Мілграма [12].

у роки Першої світової війни з'явилися перші тренажери для стрілецької підготовки військових иьотчиків у Франції та Німеччині. По суті це були звичайні гойдалки із сидінням для дьотчика та кулеметом, 3 якого пілот повинен був вчитися потрапляти в ціль під час розгойдування. Зрозуміло, схожості з реальністю було небагато, але певних позитивних результатів дьотчики досягали [11].

Із розвитком бронетанкової техніки було розроблено тренажери для механіківводіїв (як у Червоній Армії, так і за кордоном). Вони являли собою каркас і прикріплені до нього педалі, що імітували важелі керування танка та дозволяли відпрацьовувати навички управління цією бойовою машиною. Так, наприклад, у 30-х роках XX століття у Харківському бронетанковому училищі готували екіпажі для Т-26 та БТ. У цей же час американська фірма LinkTrainer почала випускати авіасимулятори. Як зазначає О. Шульман, ці тренажери належали до першого покоління [там само].

У вітчизняній вищій військовій освіті, починаючи з 90-х років XX століття, широке розповсюдження отримали статичні та динамічні тренажери, які дозволяди змоделювати управління транспортними засобами військового призначення. Імерсивний ефект у них досягався завдяки відображенню інформації на екранах в обмеженому просторі та встановленої динамічної платформи, яка уможливлювала моделювання рухів відповідно до шести ступенів свободи.

Як зазначає Г. Попова, «середовища VR $є$ засобами, що дозволяють імітувати реальні ситуації із професійної діяльності для більш ефективного формування професійних компетентностей, а інтеграція VR з реальними об'єктами та моделювання різноманітних позаштатних та аварійних ситуацій відкриває велику перспективу використання технологій VR для навчання» [6, с. 46].

Використання цих технологій сьогодні дозволяе майбутнім військовим досягнути повного занурення в освітній процес; надати здобувачам безпосередній, а не теоретичний досвід; зменшити вплив факторів, які перешкоджають сприйняттю інформації; пояснити та наочно продемонструвати опрацювання складних для розуміння тем [5, с. 25].

Найбільш цінним у таких симуляторах є максимальне наближення віртуальних умов до реальних, мождивість імітувати будь-які деталі, враховуючи фізику, створювати нескінчену кількість сценаріїв і комбінувати їх. За таких умов здобувач вищої військової освіти «стає» частиною оточуючого світу, а стрес та емоції, які відчуваються ним під час проведення тренування, максимально наближені до дійсності.

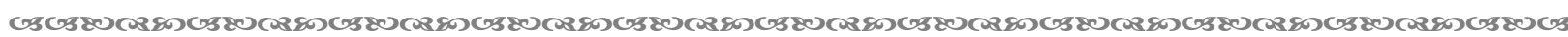
65 
Однак, найбільша критика симуляторів віртуальної реальності найчастіше пов'язана саме 3 їхньою віртуальністю, адже краще вчити дьотчика-початківця усправжній кабіні зі справжніми приладами та дисплеями по периметру, ніж у комп'ютерному оточенні, де немає ніякого тренування тактильної пам'яті [5].

VR-симулятори мають іншу перевагу. Вони набагато дешевші, що дозволяе використовувати їх у більшій кількості класів, в які неможливо закупити вкрай дорогі екзаменаційні електронно-механічні комплекси 3 фінансових міркувань. Важливо, що використання VR-симуляторів можливе йу домашніх (карантинних) умовах [16].

Окрім симуляторів, використовуються також віртуальні тренажери, під якими розуміють програмний продукт, що дозволяе здобувачу освіти отримати інформацію про місцезнаходження виробу управдіння, його внутрішню структуру, вивчити принципи роботи продукту в цілому чи його окремих компонентів, ознайомитися з повним циклом процесів перевірки працездатності продукту і підготовки його до експлуатації [11].

Якісний тренажер повинен мати зручний та інтуїтивно зрозумілий інтерфейс для швидкого пошуку необхідної інформації і їі перегляду.

Для забезпечення повної автономності навчального процесу деякі тренажери передбачають як роботу в навчальному, так і в екзаменаційному режимі. Це необхідно для того, щоб здобувачі освіти могди самостійно зрозуміти пристрій і принцип роботи досліджуваної техніки [5, с. 26].

Тренажер може бути придатним тільки для одного конкретного обладнання, а може бути і мудьтидисциплінарним. Однак, оскільки в умовах військової кафедри є багато техніки, він повинен бути міждисциплінарним. Тобто один тренажер може бути використаний для студентів різних військових спеціальностей з метою підготовки їх до правильної роботи виробу в режимі навчання і перевірки правильного засвоєння знань, умінь і навичок в режимі тестового контролю [16].

Основними вимогами до VR-тренажерів та симуляторів, що використовуються у підготовці військових фахівців, є такі:

- інтерфейс має бути максимально наближеним до реальних пультів та органів керування виробами;

- динамічна модель технологічного процесу повинна враховувати основні взаємозв' язки реальних параметрів;

- тренажер має дозволяти аналізувати та оцінювати дії здобувача освіти;

- забезпечення автономності процесу навчання шляхом уведення режиму «тренування» [11].

На сьогодні в Україні повнофункціональні тренажери для військової сфери випускають кілька підприємств, серед яких: Ніжинське підприємство «Метікод», Харківське конструкторське бюро «ХКБМ», Енергія-2000», КБ «Догіка».

Для повноцінного процесу навчання та бойової підготовки закладами вищої військової освіти України вже використовується спеціалізоване програмне забезпечення на базі віртуальної доповненої реальності VBS-3, серед яких: мультимедійні комплекси для навчання обслуги зенітних ракетно-гарматних комплексів 2 С6 «Тунгуска» та «Стріла-10», статичні тренажери зразків бойової техніки як симулятори бойових дій, обладнання взводного тренажера VBS-3 на БМП, комплексні системи організації та управління віртуальним боєм, система управління тактичної ланки «Кропива», мультимедійні комплекси для обслуговування зенітних ракетних комплексів БУК-М1 та С-300П та ін. [4].

Так, у Військовому інституті танкових військ Національного технічного університету «Харківський політехнічний інститут» під час навчання третьокурсників 
застосовуються динамічні тренажери Т-64, користуючись якими, курсанти мають мождивість навчитися керувати технікою, долати перешкоди, орієнтуватися в техніці, слідкувати за вимірювальними приладами, діяти в аварійних ситуаціях [7].

В межах підготовки пілотів у Харківському авіаційному університеті здобувачі освіти працюють із симуляторами польоту перед тим, як навчатися пілотувати на справжніх дітаках. Це дозволяе звикнути до швидкості польоту, навчитися оминати перешкоди. Також у закладі реалізують програму підготовки операторів дронів [1].

У деяких закладах вищої військової освіти курсантів навчають за допомогою VRокулярів - пристроїв, які створюють віртуальну, доповнену, змішану реальність. Вони дозволяють взаємодіяти у віртуальному просторі, створеному за допомогою 3Dмоделей та фотореалістичних кругових панорам. Наприклад, при навчанні майбутніх спеціалістів зв'язку за допомогою цього пристрою пов'язуються радіомережі, в яких працюють робітники зв'язку на реальних радіостанціях, з радіомережею, яка працює в аудиторії. Проте, вивчення рівня використання VR-окулярів на сучасному етапі дозводило зробити висновок, що їх застосування переважно обмежується вивченням засобів зв'язку та управдіння автоматизацією.

У Військовому інституті телекомунікацій та інформатизації імені Героїв Крут кафедрою кібербезпеки організовано тренувальний комплекс із кібербезпеки VITIsecurity, який являє собою сукупність програмно-технічних засобів, що дозводяе створювати, модифікувати та реалізовувати сценарії навчальних занять та тренувань 3 кібербезпеки. Цей кіберполігон уключає в себе 80 автоматизованих робочих місць для курсантів та слухачів спеціальності «Кібербезпека» даного закладу освіти [9]. Використання вищезгаданого комплексу сприяе навчанню здобувачів освіти виявленню, реагуванню, протидії та запобіганню кіберзагрозам, аналізу та розслідуванню кіберінцидентів та істотно підвищує якість освітнього процесу.

Попит суспільства на широке застосування інструментів віртуальної реальності дозводяе швидко розробляти імерсивні технологї̈ і перепрофілювати їх під конкретні потреби [2, с. 638]. У зв'язку з цим можна припустити, що в найближчі 5-10 років використання технологій занурення вийде на якісно новий рівень і вирішить більш широкий спектр освітніх завдань педагогічної площини, але їх застосування буде спрямоване на вирішення принципово різних видів навчальних завдань.

Використання технологій доповненої реальності полягає у «відродженні» цільової обстановки під час практичної стрільби. На даний момент ці технології дозволяють визначити зовнішній вигдяд цілі в секторі стрільби і доповнити ії практично створеним об'єктом. Це дасть мождивість повною мірою реалізувати один з принципів системи військової освіти - «навчання в умовах, наближених до бойових», що, безсумнівно, позначиться на підвищенні якості підготовки офіцерів, формуванні у них не тільки навичок стрільби (пошук цілі, порядок прицілювання, ураження цілі, перезарядка зброї в процесі стрільби), але і психологічної стійкості, витривалості під час бойових дій [8].

Використання імерсивних технологій у військовій освіті, безсумнівно, залишає певний відбиток на діяльності науково-педагогічних кадрів закдадів вищої військової освіти. Ключовим завданням військових фахівців, які забезпечують освітній процес, є адміністрування віртуального освітнього середовища. Безпосередньо у процесі занять родь викладача трансформується, з одного боку, на модератора, з іншого - на гіда. Однією з основних функцій військового педагога є педагогічне проєктування освітніх траєкторій у віртуальному навчальному середовищі [6].

Підвищення якості військової освіти за допомогою інструментів віртуальної реальності полягає у формуванні управлінських навичок студентів в бойових умовах і навичок прийняття рішень в умовах, максимадьно наближених до бойових. Викладач 
у цьому випадку наділений функціями контролю дій здобувача освіти й управління приватною тактичною ситуацією. Також можливе формування навичок застосування озброєння, військової та спеціальної техніки, але наразі це успішно реалізується за допомогою тренажерів різних типів.

Висновки. Таким чином, досвід використання імерсивних технологій у багатьох закдадах вищої військової освіти світу та України доводить їх дієвість та ефективність. Більше того, віртуальна, доповнена та змішана реальність $є$ черговим великим проривом у розвитку освітньої галузі, зокрема й щодо впровадження інноваційних технологій в освітній процес підготовки військових, адже тренажери та симулятори із використанням імерсивних технодогій здатні впливати на свідомість військових та готувати їх максимально наближено до реальних умов.

Перспективи подальших досліджень вбачаємо у висвітленні питання застосування імерсивних технологій у світовій практиці підготовки військових фахівців.

\section{Список використаних джерел:}

1. Експрес-курс ізкерування БП/А. URL: https://khai.edu/ua/news/ekspres-kurs-iz-keruvannyabpla/

2. Еремина И. И., Савицкая Н. Н., Садыкова А. Г. Теоретические основы и принципы построения информационной образовательной среды федерального университета подготовки ІТ-профессионалов и ее практическая реализация.Образовательные технологии и общество. 2013. № 3. С. 631-654.

3. Иммерсивность: матеріал из Википедии - свободной энцикдопедии. URL: https://ru.wikipedia.org/wiki/\%D0\%98\%D0\%BC\%D0\%BC\%D0\%B5\%D1\% 80\%D1\%81\%D0\%B8\%D0\%B2\%D0\%BD\%D0\%BE\%D1\%81\%D1\%82\%D1\%8C

4. Погіка. Конструкторське бюро. URL: https://logika.ua/zamovnyky/

5. Мусихин А.Г., Фримучков А.Н. Использование симуляторов реальной техники для обучения студентов на военной кафедре. Наука и образование сегодня. 2017. № 6 (17). С. 25-26.

6. Попова Г. В. Формування професійної навігаційної компетентності у майбутніх судноводіїв симуляційними технологіями змішаної реальності: дис. ... канд. пед. наук : 13.00.04; Херсон. держ. ун-т. Херсон, 2019. 290 с.

7. Саранцев В. Віртуальна екскурсія в «нутрощі» танка, або VR-технології в освітньому процесі. URL: $\quad$ https://armyinform.com.ua/2020/12/01/virtualna-ekskursiya-v-nutroshhi-tanka-abo-vrtehnologiyi-v-osvitnomu-proczesi/

8. Ситникова Е. С. Виртуальная и дополненная реальность: соотношение понятий. Стратегии развития социальных общностей, институтов и территорий: материалы IV Международной научно-практической конференции (г. Екатеринбург, 23-24 апреля 2018 г.): в 2-х т. Екатеринбург: Изд-во Урал. ун-та, 2018. Т. 1. С. 298-302.

9. У ЗСУ функціонуватиме надсучасний кіберполігон VITIsecurity: на кафедрі кібербезпеки розгорнуто навчально-тренувальний комплекс. URL: http://www.viti.edu.ua/news/3247

10. Указ Президента України №121/2021 «Про рішення Ради національної безпеки і оборони України від 25 березня 2021 року «Про Стратегію воєнної безпеки України». URL: https://www.president.gov.ua/documents/1212021-37661

11. Шульман O. Тренажери в армії: від кінопроєкторів до 3D-графіки. URL: https://armyinform.com.ua/2020/06/10/trenazhery-v-armiyi-vid-kinoproyektoriv-do-3d-grafiky/

12. Extended reality. From Wikipedia, the free encyclopedia. URL: https://en.wikipedia.org/wiki/Extended reality

13. HalawaniLv.Z., Feng A., Rehman S.U. Multimodal hand and foot gesture interaction for hand held devices.ACM Transactionson Multimedia Computing, Communications and Applications. 2014. Vol. 10. P. 1-19.

14. Mixed Reality, MR. URL: https://www.it.ua/ru/knowledge-base/technology-innovation/ dopolnennaja-virtualnaja-i-prochie-realnosti 


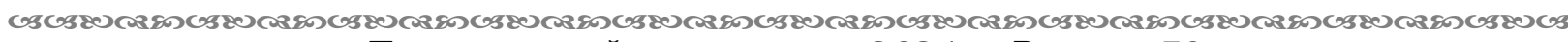
ПЕДАГОГІЧНИЙ АЛЬМАНАХ. - 2021. - ВИПУСК 50

जs

15. Osypova, N., Kokhanovska, O., Yuzbasheva, G., Kravtsov, H. Implementation of Immersive Technologies in Professional Training of Teachers. Communications in Computer and Information Science, 2021, 1308, Pp. 68-90.

16. Potkonjak V., Gardner M., Callaghan V.,Mattila P., Guetl C., Petrovich V., Jovanovic K. Virtual laboratories foreducation in science, technology andengineering. Media Psychology. 2016. Vol. 2 (19). P. 272-309.

\section{References:}

1. Ekspres-kurs iz keruvannia BPLA [Express course of UAVs control]. Retrieved from https://khai.edu/ua/news/ekspres-kurs-iz-keruvannya-bpla/ [in Ukrainian].

2. Eremina, I. I., Savitckaia, N. N., \& Sadykova, A. G. (2013). Teoreticheskie osnovy i printcipy postroeniia informatcionnoi obrazovatelnoi sredy federalnogo universiteta podgotovki ITprofessionalov i ee prakticheskaia realizatciia [Theoretical foundations and principles of building the information educational environment of the federal university for the training of IT professionals and its practical implementation]. Obrazovatelnye tekhnologii i obshchestvo, 3, 631-654 [in Russian].

3. Immersivnost [Immersiveness]. Wikipedia, the free encyclopedia. Retrieved from https://ru.wikipedia.org/wiki/\%D0\%98\%D0\%BC\%D0\%BC\%D0\%B5\%D1\%

80\%D1\%81\%D0\%B8\%D0\%B2\%D0\%BD\%D0\%BE\%D1\%81\%D1\%82\%D1\%8C[in Russian].

4. Lohika. Konstruktorske biuro [Logic. Design office]. Retrieved from https://logika.ua/zamovnyky/ [in Ukrainian].

5. Musikhin, A. G., \& Frimuchkov, A. N. (2017). Ispolzovanie simuliatorov realnoi tekhniki dlia obucheniia studentov na voennoi kafedre [Using simulators of real technology to teach students at the military department]. Nauka i obrazovanie segodnia, 6 (17), 25-26 [in Russian].

6. Popova, H. V. (2019). Formuvannia profesiinoi navihatsiinoi kompetentnosti u maibutnikh sudnovodiiv symuliatsiinymy tekhnolohiiamy zmishanoi realnosti [Formation of professional navigation competence of future ship navigators by mixed reality simulation technologies]. (Extended abstract of Candidate's thesis). Kherson State University. Kherson [in Ukrainian].

7. Sarantsev, V. (2020). Virtualna ekskursiia $v$ «nutroshchi» tanka, abo VR-tekhnolohii v osvitnomu protsesi [A virtual tour of the "inside" of the tank, or VR-technology in the educational process]. Retrieved from https://armyinform.com.ua/2020/12/01/virtualna-ekskursiya-v-nutroshhi-tanka-abo-vrtehnologiyi-v-osvitnomu-proczesi/ [in Ukrainian].

8. Sitnikova, E. S. (2018). Virtualnaia i dopolnennaia realnost: sootnoshenie poniatii [Virtual and augmented reality: correlation of concepts], Strategii razvitiia sotcialnykh obshchnostei, institutov i territorii, Materialy IV Mezhdunarodnoi nauchno-prakticheskoi konferentcii [Strategies for the development of social communities, institutions and territories, Proceedings of the IV International Scientific and Practical Conference]. Ekaterinburg [in Russian].

9. U ZSU funktsionuvatyme nadsuchasnyi kiberpolihon VITI security: na kafedri kiberbezpeky rozghornuto navchalno-trenuvalnyi kompleks [The state-of-the-art VITI security cyber range will function in the Armed Forces of Ukraine: an educational and training complex has been set up at the Department of Cyber Security]. Retrieved from http://www.viti.edu.ua/news/3247 [in Ukrainian].

10. Decree of the President of Ukraine No. 121/2021 "On the decision of the National Security and Defense Council of Ukraine" of March 25, 2021, "On the Strategy of Military Security of Ukraine". Retrieved from https://www.president.gov.ua/documents/1212021-37661[in Ukrainian].

11. Shulman, O. (2020). Trenazhery $v$ armii: vid kinoproiektoriv do 3D-hrafiky [Simulators in the army: from movie projectors to 3D graphics]. Retrieved from https://armyinform.com.ua/2020/06/10/trenazhery-v-armiyi-vid-kinoproyektoriv-do-3d-grafiky/ [in Ukrainian].

12. Extended reality. Wikipedia, the free encyclopedia. Retrieved from https://en.wikipedia.org/wiki/Extended reality [in English].

13. Halawani, Lv. Z., Feng, A., \& Rehman, S. U. (2014). Multimodal hand and foot gesture interaction for handheld devices. ACM Transactions on Multimedia Computing, Communications and Applications, 10, 1-19 [in English].

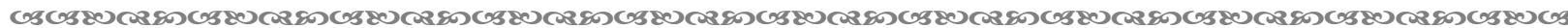


14. Mixed Reality, MR. Retrieved from https://www.it.ua/ru/knowledge-base/technologyinnovation/dopolnennaja-virtualnaja-i-prochie-realnosti [in English].

15. Osypova, N., Kokhanovska, O., Yuzbasheva, G., \& Kravtsov, H. (2021). Implementation of Immersive Technologies in Professional Training of Teachers. Communications in Computer and Information Science, 1308, 68-90 [in English].

16. Potkonjak, V., Gardner, M., Callaghan, V., Mattila, P., Guetl, C., Petrovich, V., \& Jovanovic, K. (2016). Virtual laboratories foreducation in science, technology andengineering. Media Psychology, 2 (19), 272-309 [in English].

Kokhanovska O. V., orcid.org/0000-0001-7294-173X

\section{THE USE OF IMMERSIVE TECHNOLOGIES IN HIGHER MILITARY EDUCATION OF UKRAINE: HISTORICAL ASPECTS AND MODERNITY}

The article highlights historical aspects of the experience in using immersive technologies in the preparation of future military training inhigher educational institutions of Ukraine.

It is emphasized that today immersive technologies are widely used in all fields, including military education. It is stated that the analysis of the scientific achievement of domestic scientists on the use of immersive technologies in military training showed the insufficient development of this problem, which emphasized the relevance of the topic of the article.

The essence of the concepts "immersive technologies", "virtual reality", "arugmented reality", "mixed reality" is revealed. Milgram's continuum "reality - virtuality" is highlighted, in which virtual reality acts as an environment of complete immersion in a synthetic world with the possibility of interaction.

The history of use in the military sphere in Ukraine and abroad of simulators and simulators is outlined. The emphasis is on the meaning and necessity of immersive technologies in the training of military specialists, especially the maximum approximation of virtual conditions to real ones, the possibility of simulating any details, taking into account physics, creating an infinite number of scenarios and their combinations.

Information is provided about the enterprises that now produce full-featured simulators for the military sphere and their separate types for different types of military training. The experience of using immersive simulators and simulators at the Military Institute of Tank Forces of the National Technical University "Kharkiv Polytechnic Institute," Kharkiv Aviation University, Military Institute of Telecommunications and Informatization named after Heroes Krut is highlighted.

It is noted that the use of immersive technologies in military education leaves a certain imprint on the activities of scientific and pedagogical personnel of institutions of higher military education. In particular, the key task of military specialists providing educational process is the administration of virtual educational environment.

It is concluded that simulators and simulators using immersive technologies contain a huge potential for the military training system of Ukraine, because they are able to influence their consciousness and train future specialists in conditions as close to reality as possible, thereby increasing the efficiency of training.

Key words: higher military education, immersive technologies, simulators, simulators, future military. 